\title{
A Change in Traditional Beliefs of Ethnic Minorities in Vietnam's Central Highlands Today and Some Policy - Related Recommendations
}

\author{
Assoc.Prof. Dr. Hoang Thi Lan \\ Institute of Religions and Beliefs, \\ Ho Chi Minh National Academy of Politics
}

\begin{abstract}
Summary
The Central Highlands is an adjacent highland strip with an important geopolitical position in terms of security and defense in the West Central region of Vietnam. Currently, in this area, there are 47 out of 53 Vietnamese ethnic groups residing together. The article briefly introduces the ethnic groups, in Vietnam's Central Highlands, their traditional beliefs, some changes in beliefs and ritual practices of people in the Central Highlands in recent years, proposes a number of recommendations to the State of Vietnam on preserving and promoting the traditional cultural and religious values of the Central Highlands ethnic groups to serve the sustainable development of Vietnam's ethnic minority areas.
\end{abstract}

Keywords: Ethnic minorities, beliefs, values, traditions, Central Highlands, conservation, promotion

DOI: $10.7176 /$ RHSS/11-23-01

Publication date: December $31^{\text {st }} 2021$

\section{Preamble}

The Central Highlands region of Vietnam currently has 47 out of 54 ethnic groups living together, of which the ethnic minorities with a large population include Ede, Bahnar, Sedang, Jeh-tariang. Most of the ethnic groups in the Central Highlands follow polytheistic beliefs with innocent conceptions of the divine system. The elaborate system of rituals and beliefs of the people of the Central Highlands contains many profound human values, and plays an important role in moral education, lifestyle, community cohesion, creating distinct identities of ethnic groups, making a significant contribution to Vietnam's cultural diversity. However, in recent decades, due to many reasons, the polytheistic tradition of the people of the Central Highlands has gradually faded away in both beliefs and ritual practices, putting the cultural identity of the ethnic groups at risk of being lost. Therefore, the preservation and promotion of the traditional cultural and religious values of the people of the Central Highlands is a requirement that the State of Vietnam has to lay down on realizing the goal of sustainable development of the Central Highlands.

\section{Research Methods}

In order to clarify the concept of smallholders' psychological and its influence on socio-economic development in Vietnam today, we rely on the methodological basis of dialectical materialism and materialism. history, along with the use of basic research methods such as: analytical-synthetic method, logical-historical method, deductive-inductive method, comparative and contrasting method, etc. as inheriting data from published works of scientists.

\section{Research content}

\subsection{The concept of "faith"}

The term "faith or beliefs" is understood as a general belief or belief in someone or something. The concept of faith means people's belief in something sacred and mystical.

In Vietnam, scholars from different perspectives have given different definitions of faith.

First, to judge from the aspect of belief, "faith" is religious beliefs, also known as faith (divine belief, intuitively felt, not using experimental science to prove) in gods (sacred phenomena, divine power), into the supernatural world outside humans, but have the ability to have a strong impact on people's lives in the form of giving blessing or bringing disaster. Under this concept, "faith" is the most important element constituting religion. (Dao Duy Anh, Dao Van Tap, Nguyen Van Kiem, et al.)

Second, "faith" is the whole spiritual life, the whole religion, the whole religious beliefs. This expression was used most often by President Ho Chi Minh, typically his statement in the first official meeting of the Provisional Revolutionary Government of the Democratic Republic of Vietnam in 1945: "The colonialists, the feudalistic regime implemented the policy of dividing the ethnic groups of different faiths and atheists for ease of domination and exploitation. I ask that our Government declare: Freedom of religion, Unity of religion". This concept also appeared commonly in the documents of the Vietnamese Communist Party and the State of Vietnam from 1945 to pre-1990. 
Third, in terms of form, "belief" is a cultural entity, a social entity that exists independently of organized religions, having both cultural and religious attributes such as Mother Goddess worship, Village Deity-worship, Ancestor worship, God worship. In this case, "beliefs" is also replaced by the concept of "worship" such as worshipping Village Deities, worshipping ancestors, worshipping gods/ghosts, etc. (Authors such as Toan Anh, Phan Ke Binh, Tan Viet, Ngo Duc Thinh, Nguyen Chi Ben, Nguyen Duc Lu)

However, some researchers disagree with the above distinction between belief and religion. According to this concept, types of belief such as Mother Goddess worship, Village Deity worship, ancestor worship and worship of gods/ghosts are identified with religion and called national religions because they are all in uniformity with religion, which is the admiration and worship of the sacred and the supernatural.

The documents issued by the Vietnamese Communist Party and the State of Vietnam in the renovation period, especially in the Law on Beliefs and Religion (Law No. 02/2016/QH14, National Assembly of the Socialist Republic of Vietnam), clearly distinguish between creed and religion. In Article 2 of the Law on Beliefs and Religions, the concept of belief and belief activities are construed as follows:

- Faith is human beings' beliefs expressed through rituals associated with traditional customs and practices to bring spiritual peace to individuals and communities.

- Belief activities are worshipping ancestors and sacred symbols, memorializing and honoring those who

have made meritorious services to the country and the community as well as conducting folk rituals representing historical, cultural, and social values.

In this work, we use the concept of "traditional beliefs" with the connotation of the forms of cultural, spiritual, and spiritual activities that have existed for a long time of people associated with religious beliefs. Belief, admiration, worship of things, sacred phenomena, gods, cult, souls in order to ask for protection and happiness, clearly reflecting the characteristics of ethnic culture and showing fundamental differences to religion.

\subsection{The Central Highlands region and ethnic minorities in the Central Highlands today}

The Central Highlands region of Vietnam consists of 5 provinces: Kon Tum, Gia Lai, Dak Lak, Dak Nong and Lam Dong. This area is an adjacent plateau strip located in the west of Central Vietnam with an area of about $54,500 \mathrm{~km}^{2}$, adjacent to the provinces of Quang Nam, Quang Ngai, Binh Dinh, Phu Yen, Khanh Hoa, Ninh Thuan, Binh Thuan, Dong Nai, Binh Phuoc of Vietnam and bordered by Laos and Cambodia.

The residents of the Central Highlands currently consists of three groups: local ethnic groups, Kinh people (Vietnam's most predominant ethnic group) and ethnic minorities who have just migrated from other areas.

According to the 2019 Vietnam Population and Housing Census, the Central Highlands region had 47 out of 53 ethnic groups living together with a population of 5,842,681. There were 12 ethnic groups in the Central Highlands, which included Ede, Bahnar, Sedang, Jeh-tariang, Brau, K'ho, Jarai, Mnong, Rmam, Churu, Raglai, Ma, of which the ethnic groups with a large population being Ede, Bahnar, Sedang, Jeh-tariang, etc.

The diversity of ethnic groups has created for the Central Highlands a diverse and colorful picture of cultures, beliefs and religions. Although at present, the local ethnic groups only account for about $25 \%$ of the population of the Central Highlands, with their long historical traditions, they have built up unique cultural and religious values, contributing much to enriching the cultural identity of Vietnam.

\subsection{Traditional beliefs of ethnic minorities in the Central Highlands}

Living in the majestic mountains and forests, since ancient times, ethnic minorities in the Central Highlands have built their own distinctive features of cultures and traditional beliefs. Most of the ethnic groups in this area follow polytheistic beliefs with naive conceptions of the divine system. Some types of beliefs of ethnic groups in the Central Highlands can be summarized as follows:

- Worshiping Yang (God): This is a common feature in religious activities of ethnic groups in the Central Highlands. With the concept of "animistic things", the people of the Central Highlands worship many gods. However, god is called by different names by different ethnic groups. For example, the Ede people call god "Yang"; the Bahnar, "Ong Boc" (Mr. Bok), "Ba Da" (Mrs. Ya), the Jeh-tariang, depending on a specific place, "Yang" or "Nam", and the Sedang, "Yang, Boc, Da, Kia, Kiec, etc".

In general, the forms of beliefs of the period of clan society are quite popular among the ethnic groups in the Central Highlands. The Ede people worship such gods as: Yang Ae Die (god who rules over Heaven), Yang H'Bia (wife of Ee Dieu), Yang Ae Du (son-in-law of Ae Die); Yang Mtao Kla (god of farming and hunting),

\footnotetext{
${ }^{1}$ Belief and religion have fundamental differences on some basic points. First, religion directs people to life after death, which is in another world, but in belief, people pray to gods and saints to help their lives, help them live better on earth. Second, religion has a complex structure with many elements (leaders, doctrines, canon law, rituals, organizations and followers), meanwhile belief does not have a complex structural system like religion. Third, religion has a contingent of professional practitioners, a system of Buddhist scriptures but belief has a contingent of spiritual practitioners but they are not professionally trained and it has only a few prayer texts. Fourth, religion performs its functions through its specific belief system and sanctions; Belief performs its function of regulation by beliefs, etc.
} 
Yang H'Bia Klu (wife of Mtão Kla, the god of crops), Yang Sri Mliluk (god of rice), Yang H'Bia Bao wife of the god Sri Mliluk), Yang Mtao Tlua (the god of earthly life), Kbua Lan (the wife of Mtao Tluă, the god who helps rice grow quickly), Ae Mnghi (the god of wealth), Yang Bang Sok (god of destiny), Yang Amí Ba-Ama Bah (guardian god), Yang Mnut Hra (village god), Yang Atao (ancestors, grandparents), Yang Bang Bdung Bang Bdai (the god in charge of souls of the dead), Yang Ae Yut (the god of rain), Yang Lie (the god of crop destruction), etc.

The Mnong believe that the world has three layers: heaven, earth, and the underworld; Each layer is governed by certain gods. Heaven is the abode of the supreme gods who take care of crops such as Yang Nar (god of the sun), Yang Krach (the wind god, Yang Bion, Bian (god of clouds), Yang Kua, Jong (the god of the sky) ). Yang Keng, Kang (the god who opens Heaven's door), etc. The earth layer has many different gods such as Yang Bo Krong (god of the forest), Yang Yok Nor (god of the mountain), etc. In addition, the Mnong people also worship Yang Sang (god of the house), Yang Ala Bon (god of the village), Yang Ia (god of water), Yang Po tao (king god), etc.

The Bahnar worship many gods such as Bok Kei Dei and Za Kon Keh (God of Creation), Bok Glaih (lightning god), Yang Kong (mountain god), Yang Dak (water god), Za Bok Kla (tiger god), etc. Of these gods, the most important are Bok Kei Dei and Za Kon Keh, the two gods who created the universe and all species. (According to the Bahnar people's concept, Bok Kei Dei is the most powerful god, who created the sun and stars. He sits on the blue clouds and commands other gods to take care of human affairs. He also often goes around the world to control all things. Za Kon Keh, Bok Kei Dei's wife, is the creator of heaven and earth).

The Jarai people also worship many gods such as Yang Seng (god of the house), Yang Alabon (god of trade), Yang Penla (god of water). These are gods who are very close to ordinary people. In addition, the Jarai people also worship some other gods such as earth god, lightning god, etc.

The Brau worship Yang Mat Ngai (god of the sun), Yang Bri (god of the forest), Yang Duc (god of water), etc. The K'ho worship Yang N, Du (god of creation), and Yang Mat To Ngai (god of the sun), Yang P'Nom (god of the mountain), Yang Da (god of water), Yang Bre (god of the forest), Yang Mhiu (god of rain), and Yang Koi (god of rice). The Sedang worship the god of lightning, god of water, god of rice, etc.

It can be said that, although there are different names and ways of practicing worshipping rituals in different ethnic groups, in general, worshipping Yang (god) is a popular traditional belief of ethnic groups in Vietnam's Central Highlands.

- Beliefs related to production: The Central Highlands ethnic groups have traditionally lived on forests, using a practice of slash-and-burn as one element of their farming cycle. Therefore, the system of gods and rituals related to agricultural production is quite common in this area. Due to their association with agricultural production practices, most of the Central Highlands ethnic groups such as Ede, Jarai, Bahnar, Mnong, Sedang, Jeh-tariang, Brau, Rmam, etc., all worship gods who patronize crops. According to the life cycle of upland rice from the time rice is planted to maturity, harvested and stored in warehouses, and then from warehouses back to the upland fields, each ethnic group has rituals to worship rice and festivals associated with each stage of the work. Rituals associated with agricultural beliefs of ethnic groups in the Central Highlands are carried out during the whole season of farming (from March to December every year) in order to pray and give thanks to the gods who help bring about bumper crops, of which the new rice-eating ritual is the most important ritual of many ethnic groups.

The agricultural rituals related to upland rice production of some ethnic groups in the Central Highlands can be named as follows: The Ede hold a lot of ceremonies such as finding land, cutting plants in a forest or woodland to create a field, burning plants in a forest or woodland to create a field, sowing seeds, covering roots with soil, praying for rain, worshipping the wind god, praying for rice to bloom, worshiping before the harvest, new rice-eating, celebrating the harvest, worshipping the water wharf, worshipping the spirit of rice, worshipping the rice warehouse, worshipping the cooker. The Bahnar people have some ceremonies such as opening the new production season, worshipping the cooker, conducting worship before sowing rice, evilwashing away (washing away bad things so that the rice soul does not imitate), rice-recalling (recalling the soul of the lost rice), new rice-eating ceremony, rice-threshing, granary-closing. The Jarai people conduct such ceremonies as rice-sowing, celebrating rice-blossoming-celebrating, new rice-celebrating, rice-storing, etc. The Mnong people officiate such ceremonies as worshipping the land God for clearing the land for cultivation, offering a prayer of of thanks to the ax, upland field-burning, asking for the opening of the granary, worshipping to rice before it is taken out of the granary, banning the cutting of plants in a forest to create upland fields, sowing rice, worshipping new rice, rice-threshing, rice- bathing, worshipping sunshine and rain, etc. Other ethnic groups like Jeh-tariang, Sedang, K'ho, etc., also hold ceremonies of offering sacrifices to gods related to each stage of the rice production cycle.

- Beliefs related to human life cycle: Life cycle beliefs are beliefs related to human life from birth to death, performed through a system of basic rituals such as: rituals in childbirth, marriage, funerals, medical treatment. Rituals related to important milestones in the cycle of a person's life have a great influence on the social life of a 
community or ethnic group. It is an important factor contributing to the cultural identity of each ethnic group.

Like ethnic groups in other areas of Vietnam, the ethnic groups in the Central Highlands also have taboos and a system of rituals related to the human life cycle. The Ede people have rituals such as worshipping ceremony when the mother is pregnant, worshiping ceremony before giving birth, the naming and ear-blowing ceremony, full-month worshiping ceremony, full-year worshiping ceremony (a growing season), full-year offering ceremony. 3 years old (three growing seasons), 7-year-old worshiping ceremony (seven growing seasons), 15-year-old worshiping ceremony (15 growing seasons), adult worshiping ceremony (17 growing seasons), wedding ceremony, and health worshiping ceremony for husband and wife children, annual health offerings for each family, health offerings for homeowners when they are in their $50 \mathrm{~s}, 60 \mathrm{~s}, 70 \mathrm{~s}, 80 \mathrm{~s}$, funerals for ghosts, burial ceremonies, etc. There are rituals such as worshiping ceremony during pregnancy, worshiping ceremony to protect the fetus, worshiping ceremony for mothers after giving birth, opening eyes for children, umbilical cord- cutting ceremony, thanksgiving ceremony for grandparents for raising and taking care of children. Child-naming ceremony and spirit-worshiping ceremony for children, hair-cutting ceremony and earpiercing ceremony, ear-blowing ceremony, tooth-grinding ceremony, adulthood ceremony, buffalo-eating ceremony to repay gods, worshipping ceremony for the elderly's health, etc.

Similarly, other local ethnic groups in the Central Highlands such as Bahnar, Sedang, Jeh-tariang, Mnong, Rmam, Churu, Jarai, Ma also have many taboos and rituals related to the human life cycle.

In the life-cycle rituals of some ethnic groups in the Central Highlands, the burial ceremony is considered the most important one. Leaving the grave is the last ritual where the living say goodbye to the deceased to the ghost village, completely removing the relationship between the dead and the living. The people of the Central Highlands believe that, only after the ceremony of leaving the grave, the soul of a dead person can be reborn in another life and continue a new life. Only then will the living fulfill their obligations to the deceased. Therefore, leaving the grave is the biggest and most fun ritual, which is meticulously prepared by the people of the Central Highlands from the construction of grave houses and statues, to the preparation of offerings, and the organization of sacrifices for the deceased.

- Talismans, ghosts (magic): Traditionally, many ethnic minorities in the Central Highlands have faith in talismans and magic. Worm amulet, according to the concept of the people of the Central Highlands, is an object containing supernatural forces, the devil has the ability to command others, to spread disaster, disease, and death to others according to the will of the user. Ma Lai (Ghost Lai) is considered by the people of the Central Highlands to be a human-shaped demon, specializing in gutting people and eating corpses. Since time immemorial, belief in talismans and ghosts has been maintained by the people of the Central Highlands through word of mouth between generations with extremely macabre stories. Beliefs in charms, ma lai have caused many villages in the Central Highlands to suffer cruel tragedies (killing people, burying children alive, etc.). Currently, the number of people in the Central Highlands who still believe in the power of charms and ma lai is not much, but to a certain extent, talismans and ma lai still have a negative effect on the life of part of the inhabitants.

In general, the local ethnic groups in the Central Highlands have a rich and wide variety of beliefs, containing many profound human values. The belief system of the people of the Central Highlands plays an important role in moral education, lifestyle, community cohesion, contributing to creating the unique identity of the Central Highlands ethnic groups and making a significant contribution to the value of diversity of Vietnamese culture.

\subsection{A change in traditional beliefs of ethnic minorities in the Central Highlands today}

In recent decades, due to the impact of many factors such as globalization trend; opening-door policy, international integration and innovation in guidelines and policies on ethnicity, religion, belief and culture of the Vietnamese Communist Party and the State of Vietnam, socio-economic development, population structure change, the penetration and development of religions, etc. have made great changes in the cultural values and traditional beliefs of the people of the Central Highlands.

In addition to traditional folk beliefs, among the ethnic groups in the Central Highlands in recent decades, there have been four religions: Catholicism, Protestantism, Buddhism and Caodaism, among many other new religious phenomena such as Ha Mon, Po Khap Brau, Amí Sara, Charismatic Renewal, the Cross of Jesus Christ, the Vietnamese Evangelical Church of Christ, etc. In particular, Protestantism has developed extraordinarily and set itself the ultimate aim of abolishing traditional culture and beliefs, causing great disturbances in the social and cultural life of the people of the Central Highlands.

In ethnic minority communities practising Buddhism and Caodaism, some traditional religious rituals are still maintained by the inhabitants. But in ethnic minority groups practising Catholicism and Protestantism, the traditional beliefs of the people have undergone great changes. Under the influence of doctrines, canon law, and rituals of Catholics and Protestants, the concept of the traditional divine system with its power over heaven, earth, and people has gradually faded and disappeared. Today, in Catholic and Protestant villages, most people no longer believe in punishment or help from traditional gods. Therefore, many traditional rituals related to the 
plant life cycle such as awakening the soul of rice, sowing seeds, eating new rice, etc., no longer exist; the festivals of eating buffalo to celebrate the new communal house of the Sedang, Jarai, and Jeh-tariang people are completely absent from Catholic and Protestant villages. Weddings, funerals in these villages are performed entirely in the rituals of religions. Many Catholics and Protestants are no longer eager to participate in national festivals. The partial or complete disappearance of traditional religious rituals in a part of the people of the Central Highlands due to the conversion of beliefs from polytheism to monotheism (Catholicism, Protestantism) has broken down the traditional culture, creating the risk that the ethnic cultural identity of the ethnic groups will fade away.

In recent years, due to the policy of cultural integration of the Vietnamese Catholic Church, now, in some Catholic villages, some religious rituals have been maintained by the inhabitants but in the form of Consciousness are traditional cultural activities, which have absolutely no spiritual meaning. For example, in some villages of the Sedang Catholic people in Kon Tum, the ceremony of installing water troughs is still performed, but only includes things such as checking the water pipes and repairing the water pipes (replacing the bambusa balcooa with plastic pipes) and gather together to eat, drink and sing. Even in Catholic villages that do not have water troughs because they move to a lower area, the inhabitants still perform the ceremony on one day of the year but there is no worshipping ceremony, but only do some repairs to dug wells and eat together like a traditional cultural festival.

In the non-Catholic and Protestant communities, the changes in the living environment lead to significant changes in the beliefs and religious practices of the ethnic groups of the Central Highlands. Nowadays, people's belief in the traditional divine system has faded significantly. The gods have become less sacred and some gods are only present in the stories told by the elderly. A survey shows that, currently, 39.19\% of 148 inhabitants of the Central Highlands believe that the gods of mountain, forest, and river bestow blessing, $11.49 \%$ believe that there is punishment and $59.46 \%$ do not believe in blessing or punishment, $18.24 \%$ have faith in sacred objects and $80.41 \%$ do not believe that animists can give blessing or administer punishment.

The fact that beliefs fade away leads to a decline in the practice of sacrifice to the gods. A survey shows that $2.09 \%$ of the inhabitants of the Central Highlands pray to the gods of forest, river and mountain on Tet holidays, $4.73 \%$ pray when they are sick, and $11.49 \%$ pray. when they are going to build a new house and $77.03 \%$ do not prayat all on the above-mentioned occasions. As for other sacred objects, $52.7 \%$ of those surveyed pray on holidays and Tet, $4.73 \%$ pray when sick and $34.46 \%$ do not pray at all ${ }^{1}$.

The position of the god of thunder, god of water, god of rice is no longer present in the minds of modern farmers, so many agricultural rituals are no longer maintained regularly. In many villages of the Sedang, Bahnar and Jeh-tariang people, rice rituals and processions except the new rice-eating ceremony (to celebrate the completion of harvest) are no longer held. Even in many places, the new rice-eating festival disappeared long ago but it has recently been restored by the government. Some other ceremonies and festivals such as water trough worshiping ceremony (Sedang people), water drop festival (Bahnar people), although still maintained in many villages, are also performed with many stages omitted and their spiritual meanings fading away a lot. The buffalo-eating festival is also rarely organized because it is no longer suitable for the new conditions.

The life of the ethnic groups in the Central Highlands is now less dependent on forestS, so the belief in forest gods and tiger gods has also disappeared. The tree mentioned in the traditional concept of the Central Highlands ethnic groups is a place of customs clearance between heaven and earth, a symbol of the gods, now mainly has a decorative meaning, there are few sacrificial rituals, taboo when erecting trees. mentioned as a tradition. The traditional Rong house (communal house) of ethnic groups in the Central Highlands is both a place to store spiritual values and a center of community cultural activities, but now, for many reasons, the Rong house in the Central Highlands is also losing its sacred meaning. With the State's financial support, many new Rong houses of the villages were often "concreted" and have lost their traditional values. Many Rong houses today no longer have a spiritual and sacred meaning, but are merely a meeting place the inhabitants to get together and organize common events of the village. Even in many localities, the Rong house is finished and people do not use it because the village has its own hall. According to the statistics of the Department of Culture, Sports and Tourism of Kon Tum province, in Kon Tum province, there are 440 villages that have communal houses. Of these, 304 villages still keep their traditional communal houses, and 136 communal houses are built with modern materials. In Kon Tum city, in 56 ethnic minority villages with communal houses, there are 40 communal houses built with concrete and cement materials (accounting for $71.4 \%)^{2}$.

The customs and rituals related to the human life cycle such as: naming ceremony, unlucky ceremony, health ceremony, coming of age ceremony, wedding ceremony, funeral ceremony, burial ceremony, etc., are also summarized with some steps skipped. Most of the Central Highlands women today, when giving birth, go to a

\footnotetext{
${ }^{1}$ Ho Chi Minh National Academy of Politics, Synthesize fieldwork materials conducted in the provinces of Dak Lak, Gia Lai, Kon Tum, Lam Dong in the period of 2018-2020 to serve the State-level scientific topics: New issues about religions and beliefs in ethnic minorities in our country today, Code CTDT16/20.

${ }^{2}$ http://baovanhoa.vn/van-hoa/Đời sống văn hóa/Nhà rông bị bê tông hóa: băn khoăn nhưng không tránh khỏi.
} 
local clinic to be cared for instead of going to the forest to give birth alone as before, so many birth-related rituals such as praying for an easy birth, throwing a pestle to ward off evil spirits when a child is born, asking for the soul of a newly deceased person to return to the soul of an infant, etc., are no longer performed. When getting sick, most people in the Central Highlands have sought scientific cures, so the rituals of worshiping ghosts, charms, and magic are performed in very few places. In many weddings of the ethnic groups of the Central Highlands, gongs no longer appear, celebration parties are held at the family or in the hall, at the communal house of the village, with a band and high-powered sound system serving local singers and invited guests like those weddings conducted in all regions of the country. Although sacrificial rituals are still performed by the inhabitants, they are only performed perfunctorily.

A survey carried out in the Central Highlands communities who still conduct traditional religious activities, with the question: "How does your family perform the following rituals?" obtained the results as follows:

\begin{tabular}{|l|l|l|l|l|l|l|l|l|}
\hline Ritual & \multicolumn{2}{l|l|}{$\begin{array}{l}\text { Conducted } \\
\text { traditionally }\end{array}$} & \multicolumn{2}{l|}{$\begin{array}{l}\text { Some rituals } \\
\text { abandoned }\end{array}$} & \multicolumn{2}{l|}{ Some rituals added } & \multicolumn{2}{l|}{ No response } \\
\hline & $\begin{array}{l}\text { Number } \\
\text { (person) }\end{array}$ & $\begin{array}{l}\text { Percentage } \\
(\%)\end{array}$ & $\begin{array}{l}\text { Number } \\
\text { (person) }\end{array}$ & $\begin{array}{l}\text { Percentage } \\
(\%)\end{array}$ & $\begin{array}{l}\text { Number } \\
\text { (person) }\end{array}$ & $\begin{array}{l}\text { Percentage } \\
(\%)\end{array}$ & $\begin{array}{l}\text { Number } \\
\text { (person) }\end{array}$ & $\begin{array}{l}\text { Percentage } \\
(\%)\end{array}$ \\
\hline Birth & 22 & 14,86 & 88 & 59,46 & 9 & 6,08 & 29 & 19,59 \\
\hline Wedding & 61 & 41,22 & 54 & 36,49 & 19 & 12,84 & 14 & 9,46 \\
\hline Funerary & 52 & 35,14 & 75 & 49,32 & 9 & 6,08 & 14 & 9,64 \\
\hline
\end{tabular}

Source: Ho Chi Minh National Academy of Politics, Synthesis of survey materials, completed in Dak Lak, Gia Lai, Kon Tum, Lam Dong provinces in the period of 2018-2020 to serve a State-level scientific topic: "New issues about religions and beliefs of ethnic groups of our country today, Code CTDT16/20.

Besides, due to living in the community with Kinh people, some ethnic communities in the Central Highlands have absorbed more Kinh people's religious rituals (especially in urban areas). For example, in some Jarai families residing in Ia Mnong commune, Chu Pah district, Gia Lai province, the inhabitants celebrate the death anniversary of the dead; ancestral graves are built of cement and reinforced steel, with steles bearing the names of the dead. Tombs are built of bricks, with curved roofs made from corrugated iron or concrete like those of dead Kinh people with a small urn of incense instead of a rice house. The custom of leaving graves in many places is no longer practised. Instead, there is a burial ceremony like the Kinh people, the sculpting of tomb statues and worshipping rituals are no longer traditionally carried out.

In general, in recent decades, with the attention and efforts of the Vietnamese government, it is undeniable that the socio-economic life of the people of the Central Highlands has improved considerably according to the positive direction. But a paradox in the development of the Central Highlands is that while the material and spiritual life of the people of the Central Highlands is improved rapidly and many outdated customs are being abandoned, cultural beliefs and traditional spiritual values of ethnic groups are confronting enormous challenges. The fracture of traditional culture, the fading of beliefs and practices of traditional spiritual and cultural values, the lack of selective absorption of foreign cultural factors, beliefs, etc., are causing the ethnic groups in the Central Highlands to be in danger of disappearing and losing their identity. This is a big problem that needs considerable from the Vietnamese government today. Therefore, how the Central Highlands ethnic groups can integrate and develop with other ethnic groups in Vietnam, integrate with other ethnic groups in the world without losing their own identity and what can be done to promote the development of the Central Highlands commensurate with is potential and position but still ensure a stable living environment and sustainable development for ethnic groups, especially inhabitants, are big problems for the Vietnamese government.

\subsection{Recommending policies on preserving and promoting cultural values and beliefs of ethnic groups in the Central Highlands}

In order for the cultural values and beliefs of the peoples of the Central Highlands to be preserved and promoted for the sustainable development of the ethnic groups here, we would like to make the following recommendations:

* For the State of Vietnam:

- Firstly, it is necessary to continue to supplement and perfect the policy of preserving and promoting the cultural values of ethnic minorities, review the policies on religions, beliefs and cultures, remove overlapped and inappropriate legal documents related to culture and beliefs, introduce regulations on conservation and promotion of religious values into the Law on Beliefs and Religions and the Law on Cultural Heritage.

Second, it is necessary to map out an investment strategy and plan for the development of culture in general and ethnic minority culture in particular; have appropriate mechanisms and policies to preserve and promote traditional cultural and religious values of ethnic groups in the building of Vietnamese culture.

Third, attention should be paid to raising awareness among officials in the political system and people in general, and ethnic minorities in particular of guidelines and policies to preserve and promote cultural values of ethnic minorities, promoting the educating of the young generation from different ethnic groups on the history, 
cultural values and beliefs of their own groups.

Fourth, it is necessary to strengthen the renovation of management to preserve and promote the cultural and religious values of ethnic minorities in Vietnam in general, in the Central Highlands in particular, to deal with the so-called "poor management" of the religious affairs.

Fifth, it is necessary to step up the collection, preservation and promotion of ethnic cultural identities in each specific region and ethnic group, to select and preserve the cultural values, beliefs, customs and habits still relevant to meet the needs of the native inhabitants in each region, each ethnic group, and on that basis to canvass ethnic people to actively preserve and promote these values. For ethnic groups in the Central Highlands, it is necessary to pay attention to the cultures of communities, gongs, communal houses, long houses, and the belief system of worship of forest gods, mountain gods, water gods, etc.

Sixth, ministries, departments, branches and central mass organizations such as the Committee for Ethnic Minority Affairs, the Ministry of Culture, Sports and Tourism, the Government Committee for Religion, etc., need to promote the initiative in directing, managing the conservation and development of ethnic groups' cultures and beliefs. The Committee for Ethnic Minority Affairs shall coordinate with cultural agencies in implementing ethnic policies, associated with socio-economic and cultural development policies. The Government Committee for Religious Affairs closely cooperates with the culture sector in the state management of beliefs and religion. The Ministry of Culture, Sports and Tourism advises the Government on cultural policies suitable to each region, including the Central Highlands; formulating strategies and plans to preserve and promote cultural and religious values of ethnic groups; cooperating with localities in reviewing, making statistics and making records of cultural heritage; implementing projects and programs to preserve and promote the cultural and religious values of ethnic groups; formulating regulations on promoting socialization of conservation and promotion of cultural and religious heritages of ethnic minorities.

* For local authorities in the Central Highlands, they need:

- to direct and organize the effective implementation of the task of preserving and promoting the cultural and religious values of the ethnic groups in the area, based on the guidelines and policies of the Party and the State.

- to cooperate with ministerial-level agencies in formulating plans and facilitating the implementation of programs and projects to preserve and promote cultural and religious values of ethnic minorities.

- to actively and proactively take advantage of available financial resources, both local and outside, besides the investment from the State, to develop culture, create favorable conditions for the ethnic groups to preserve and promote the values of their cultures, religions, beliefs and traditional festivals and enjoy progressive cultural values, take the initiative in building models, taking measures to preserve and develop appropriate cultural and religious values.

- to pay attention to building a suitable living environment for the peoples of the Central Highlands, especially recreating the specific environment (i.e. forests) for the ethnic groups to ensure the livelihoods of the native inhabitants of the Central Highlands and the maintenance of the original environment for their cultures and beliefs.

- to promote the role of village elders, village chiefs, witches, shamans and other prestigious people in ethnic groups as folk artisans and folk intellectuals, because they have important advantages of maintaining traditional cultures and beliefs, preserving national cultural identity. In addition, it is necessary to help them raise awareness and sense of conservation, and pass on cultural values and traditional beliefs to the next generation.

- to step up the work of socializing the conservation and promotion of cultural, religious and belief values of the ethnic groups, with importance placed on the conservation of "dynamic", that is, not separating cultural activities, beliefs out of the living environment of the community. Only then will the people of the Central Highlands fully realize the fundamental meaning and motivation of preserving cultural values and beliefs, and they themselves will be important subjects who resolve cultural conflicts successfully.

- to implement remuneration policies and practices on those who do the work of preserving and promoting cultural values of ethnic groups as well as ethnic artisans and folk artists.

- to pay much attention to consolidating and developing national culture in ethnic minority areas, especially border areas, to the elements of national culture, the relationship of culture country with ethnic culture, popular culture and foreign culture. On the basis of developing traditional cultural values and beliefs of the Central Highlands ethnic groups in association with national culture and popular culture, it is necessary to continue to take effective measures to prevent negative impacts of foreign cultures.

\section{Conclusion}

The ethnic groups in the Central Highlands of Vietnam have an extremely rich and diverse religious life. The belief system of the ethnic groups of the Central Highlands plays an important role in social life, contributing to the creation of unique cultural identities of the ethnic groups. However, in the new social context, traditional beliefs of ethnic groups in the Central Highlands are undergoing great changes, posing many challenges to the 
State of Vietnam's ethnic, cultural, religious and belief work. Vietnam. The restoration, preservation and promotion of the traditional cultural and religious values of ethnic groups in the Central Highlands will contribute to raising the people's awareness, creating an important catalyst for community cohesion, helping Central Highlands people select and absorb positive and appropriate foreign cultural and religious values, and at the same time preserve good cultural values in the cultural identity of ethnic groups, contributing to the sustainable development of the Central Highlands.

\section{References}

1. Committee for Ethnic Minority Affairs (2020), Summary report on research results of scientific topic: New issues of religions and beliefs in ethnic minority areas in our country today. Code: CTDT.34.18/16-20. Hanoi.

2. National Assembly of the Socialist Republic of Vietnam (2016), Law No. 02/2016/QH14 Law on Beliefs and Religions.

3. Pham Thi Hoang Ha (editor) (2018), Ethnic-religious relations in ethnic minority areas of Vietnam today, Political Theory Publishing House, Hanoi.

4. Vietnam Academy of Science and Technology (2014), General report on the topic: Religious issues relating to sustainable development of the Central Highlands. Code: TN 3X6. Hanoi.

5. Le Van Loi (Editor) (2018), Resolving ethnic and religious issues in Vietnam today, Political Theory Publishing House, Hanoi

6. Cultural Research Institute (2019), Ethnic culture in the Central Highlands: traditions, changes and issues arising, Social Science Publishing House, Hanoi.

7. Jacques Dournes (2018), Forest, Woman, Madness - Going through the Jarai paranoid domain, (translated and introduced by Nguyen Ngoc), Knowledge Publishing House.

8. Nguyen Van Ku, Luu Hung, Le Van Thao, Luong Thanh Son (2019), Ethnic groups in the Central Highlands, World Publishing House.

9. Georges Condomina (By multiple translators) (2020), We are eating forests. World Publishing House. 